\title{
功作の記憶の再生と再認に及ほす多様性練習の奻果
}

一遂行前と遂行後における情報処理活動に蔇目した検討一

\author{
工 藤 孝 幾1)
}

\section{The effect of variability of practice upon recall and recognition of motor memory: Analysis based upon the information processing activities during pre- and post-perfomance}

\author{
Koki Kudo ${ }^{1}$
}

\begin{abstract}
The purpose of this study was twofold, one was to examine whether the effects of variability of practice upon retention and transfer can be found not only in recall but also in recognition of motor memory. The second objective was to examine whether those effects are due to the formation of motor schemata (Schmidt, 1975) or to the contextual interference effect (Battig, 1979).

Sixty-four subjects performed a novel aiming task designed by Kudo (1989), and were randomly assigned to the following four groups. A Constant group practiced 96 trials of the same target, whereas a Random group practiced 96 trials of four different targets in a random order. The remaining two groups also practiced 96 trials of four different targets, but the practice schedules were changed. A Block 6 group practiced at one target for six trials, whereas a Block 12 group practiced at one target for 12 trials continuously. All groups were tested on new targets immediately and one week later.

The results were as follows. (1) Almost the same results were obtained in both recall and recognition measures. (2) Comparing the test performances of a Constant group with the two blocked practice groups, inconsistent results were obtained. These results suggest that "the variability of practice hypothesis" was not neccessarily supported. (3) Large decrements of performance in the one week retention interval were found in the blocked practice groups, whereas the random group's decrement was very small. Moreover, the random group's performance in the transfer test was better than those of blocked groups. These results suggest that facilitation of retention and transfer by the variability of practice might be due to the contextual interference effect. (4) Programming time to perform the aiming response in practice session differed according to the practice schedule conditions. That is, the random group was the longest, while the constant group was the shortest, and the blocked groups were intermediate. These results supported Lee and Magill's (1985) interpretation of the superiority of random scheduling over the blocked scheduling.

Key words: schema theory, variability of practice, contextual interference, recall, recognition
\end{abstract}

Japan J. Phys. Educ., 36: 15-26, June, 1991.)

1）福島大学教育学部

干 960-12 福島市松川町浅川字直道 2 番地

1. The Faculty of Education Fukushima University Matukawamachi, Fukushimashi, Fukushima (960-12) 


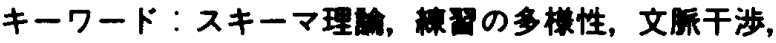
再生, 再跳

\section{I. 序}

Schmidt $^{24)}$ がスキーマ理論を公表して以来, この理論から導き出される多様性練習仮説 (Moxley) ${ }^{19)}$ を心に, 多くの検証実験が行われ てきた.工藤 ${ }^{15)}$ は，このことに関する文献の多く が仮説を支持する結果を得ているものの，矛盾 する結果す報告されていること，またその原因 の1つが，成人を被験者とした研究において， 新たなスキーマの形成を必要とする動作課題が 用いられていないためであることを指摘してい る。また， も1 つの問題として, 従来の研究 が再生スキーマの検討の方に集中しており，再 認スキーマの形成に成しては十分に検討されて いないことも挙げている，そこで，本研究の目 的の 1 つは, 成人を被匼者とし，工藤 ${ }^{15)}$ が考案し た新たな動作課題を用いることによって，動作 の再生と再認の 2 つの機能に対する多様性練習 の効果について調べることである。

ところで，多様性練習の効果は，スキーマと いう概念以外です説明することができる. Shea and Morgan ${ }^{27)}$ は, 言語学習の領域で明らかに された分脈干涉効果 (Batting ${ }^{1)}$ ) を，動作の学 習において検討している，分脈干涉奻果とは， 練習セッションの試行相互の干涉は，練習時の パォーマンスの低下をすたらすが，保持ある いは転移を促進するというすのである. Shea and Morgan は，動作課題を用い，䙓数の動作 を 1 回ごとにランダムな順序で練習するランダ ム群（高分脈干涉条件）と，1つの動作を連続 して練習してから次のパターンに移るといらブ ロック練習群（低分脈干啮条件）とを比較し， 前者の方が保持と枟移で優れているという結果 を報告しており，その後の研究においても同様 の結果が得られている (Del Rey ${ }^{3)}$, Del Rey, et al. ${ }^{4), 5), 6)}$, Gabriele, et al. ${ }^{7), 8}$, Goode and Magill'), Lee and Magill' ${ }^{16)}$, Lee, et al. ${ }^{18)}$, Pigott and Shapiro' ${ }^{23)}$, Whitehurst and Del Rey $^{32)}$, Wrisberg and Mead ${ }^{33)}$ ).
さて，練習に多様性をむたせることが，練習 時のパフォーマンスを低下させ，保持と転移を 促進するといら点では，スキーマ理論も分脈干 涉効果も，まったく同じ結果を予想している. ただ，前者は練習のスケシュールを問題としな いのに対し，後者はそれを最む重要な要因と考 えている. Lee and Magill ${ }^{16)} は$ はンンスタント 条件と比べ多様性練習条件は，練習スケジュー ルがランダムな場合は優れた結果が得られてい るが，ブロック化された場合には差がみられな いと述へている。このことは，多様性練習の効 果は，むしろ分脈干渉によるものであることを 強く示唆しているが, その後の研究では,ブロッ ク条件であコンスタント条件よりは優れている といら結果も報告されており(Del Rey, et al. ${ }^{6}$, Pigott and Shapilo ${ }^{23)}$, Lee, et al. ${ }^{18)}$, Turnbull and Dickinson ${ }^{29)}$ )，明確な結論を下すまでには 至っていない，そこで本研究では，多様性と分 脈干涉に富むランダム条件，多様性に富み分脈 干涉の低いブロック条件，多様性と分脈干涉と すに低いコンスタント条件を設定し，またブ ロック条件内に, 分脈干涉の程度の異なる 2 水 準を設けることにより，以上の点に対する検討 も試みる。

ところで Lee and Magill ${ }^{17)}$ は，ブロック条件 では“action plan”を受動的に想起すればいい のに対し，ランダム条件では試行度に再構成す る必要がありここような動作遂行のための事 前の情報処理の違いが，保持と転移の差を生む 原因となっているのではないかと考えている. Lee, et al. ${ }^{18)}$ は, 動作開始のための準備時間がブ ロック条件よりランダム条件の方が長いことを 報告しているが，これは Lee and Magill の解釈 を窔付ける1つの証拠となっている，たた，動 作遂行前の情報処理ばかりでなく，遂行後の情 報処理の仕方にる条件間差があると考えること ができる、つまり，ブロック条件よりランダム 条件の方が，毎回入念な KR 情報の処理を行う 必要があり，これもランダム条件の方が優れて いるといら結果の原因になっている可能性があ る. 本研究では, Lee, et al. ${ }^{18)}$ が調べた準備時間 


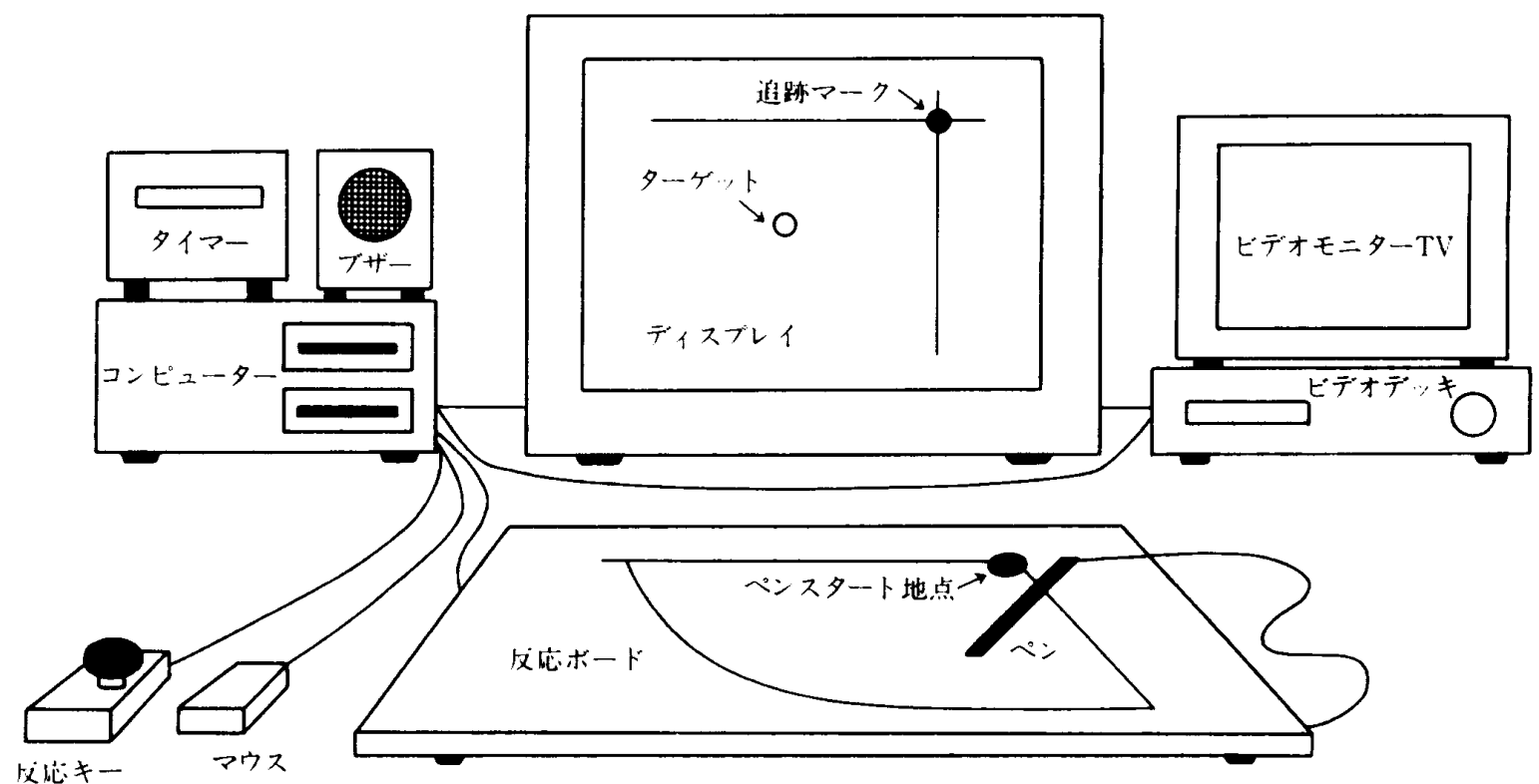

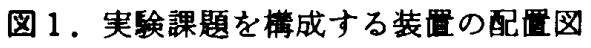

と同時に, KR の情報処理に関わる時間をる測 定することにより，以上の点についても考察す る.

\section{II. 方 法}

\section{1. 被鏂者}

19 歳から 21 藏までの, 右手利きの大学生男 女 64 名を被験者とした。

\section{2. 实験課昌}

図 1 は，本実験で用いた動作課題を構成する 装置を示したものである.ディスプレイには， 追跡マーク（直径 $5 \mathrm{~mm}$ の白色の円）とター ゲット（直径 $5 \mathrm{~mm}$ の黄色の円）が表示される. 追跡マークの移動する角度と距離は, 被耠者が 保持したベンのボード上での動かし方によって 決定される。ここでの課題は, ベンをボード上 で適切に動かすことによって，ターゲットの中 に追跡マークを正確に入れることである.

追跡マークを動かすために被験者に要求され た動作は，ボード右角のスタート地点から左下 方の円孤の外側まで，ある方向に，ある一定の 速度で直線的にペンを動かすことである，追跡 マークの移動する角度はヘンンの移動方向によっ て，また距離は速度によって決定される。この とき，追跡マークのディスプレイ上の移動距離
( $\mathrm{Ycm})$ と, ボード上のペンの移動速度 $(\mathrm{Xcm} /$ $\mathrm{sec}$ ）とは, $\mathrm{Y}=0.35 \mathrm{X}$ といら関係に設定され た。またディスプレイ上の追跡マークの移動角 度は，ボード上のペン移動方向に対して，常に 左周りに 20 度ずれるように設定された。

ペンの動きを読み取るために，反応ボードと してデジタイザーを使用した。デジタイザー上 のペン位置の座標值はコンピュータにインプッ トされ，ペンの移動角度と距離が算出された。 座標値の計測区間は，スタート地点から円孤ま での $20 \mathrm{~cm}$ の区間の, 円孤寄り $15 \mathrm{~cm}$ の区間と した。サンプリングレートを 1 秒間 40 回とし, 各ポイント間ごとに角度と速度を求め，その平 均値に基ついて，追跡マークの移動角度と距離 が決定された。なおその際, 角度の標準偏差, 速度の変動係数を算出することにより，ペ移 動中の方向や速さの摇れの程度を検出し，いず れか一方です一定の基準を越えると告告が鳴 り，データがキャンセルされるよらにした，基 準值を設定するに当たっては，客钼的な基準と いらすのがないので, 予備実験として本研究と は異なる 5 人の被験者に様々な方向と速度でぺ ン移動を行わせ，そのときの上記の変数の值を 参考にして決められた（詳しくは文献 15）。 
衰1。各群の練習スケジュール

\begin{tabular}{|c|c|c|c|c|c|}
\hline \multirow{2}{*}{ 群 } & \multirow{2}{*}{$\mathrm{N}$} & \multicolumn{4}{|c|}{ 練習 スケシュール } \\
\hline & & 第 1 セット & 第 2 セット & 第 3 七ット & 第 4 七ット \\
\hline C -1 & 4 & $\mathrm{~A} \times 24$ & $\mathrm{~A} \times 24$ & $\mathrm{~A} \times 24$ & $\mathrm{~A} \times 24$ \\
\hline-2 & 4 & $\mathrm{~B} \times 24$ & $\mathrm{~B} \times 24$ & $\mathrm{~B} \times 24$ & $\mathrm{~B} \times 24$ \\
\hline-3 & 4 & $\mathrm{C} \times 24$ & $\mathrm{C} \times 24$ & $\mathrm{C} \times 24$ & $\mathrm{C} \times 24$ \\
\hline-4 & 4 & $\mathrm{D} \times 24$ & $\mathrm{D} \times 24$ & $\mathrm{D} \times 24$ & $\mathrm{D} \times 24$ \\
\hline B6-1 & 4 & $\mathrm{~A} \times 6, \mathrm{~B} \times 6, \mathrm{C} \times 6, \mathrm{D} \times 6$ & $\mathrm{~A} \times 6, \mathrm{~B} \times 6, \mathrm{C} \times 6, \mathrm{D} \times 6$ & $A \times 6, B \times 6, C \times 6, D \times 6$ & $A \times 6, B \times 6, C \times 6, D \times 6$ \\
\hline-2 & 4 & $\mathrm{D} \times 6, \mathrm{C} \times 6, \mathrm{~B} \times 6, \mathrm{~A} \times 6$ & $\mathrm{D} \times 6, \mathrm{C} \times 6, \mathrm{~B} \times 6, \mathrm{~A} \times 6$ & $\mathrm{D} \times 6, \mathrm{C} \times 6, \mathrm{~B} \times 6, \mathrm{~A} \times 6$ & $\mathrm{D} \times 6, \mathrm{C} \times 6, \mathrm{~B} \times 6, \mathrm{~A} \times 6$ \\
\hline-3 & 4 & $\mathrm{~B} \times 6, \mathrm{~A} \times 6, \mathrm{D} \times 6, \mathrm{C} \times 6$ & $\mathrm{~B} \times 6, \mathrm{~A} \times 6, \mathrm{D} \times 6, \mathrm{C} \times 6$ & $\mathrm{~B} \times 6, \mathrm{~A} \times 6, \mathrm{D} \times 6, \mathrm{C} \times 6$ & $\mathrm{~B} \times 6, \mathrm{~A} \times 6, \mathrm{D} \times 6, \mathrm{C} \times 6$ \\
\hline-4 & 4 & $\mathrm{C} \times 6, \mathrm{D} \times 6, \mathrm{~A} \times 6, \mathrm{~B} \times 6$ & $\mathrm{C} \times 6, \mathrm{D} \times 6, \mathrm{~A} \times 6, \mathrm{~B} \times 6$ & $\mathrm{C} \times 6, \mathrm{D} \times 6, \mathrm{~A} \times 6, \mathrm{~B} \times 6$ & $\mathrm{C} \times 6, \mathrm{D} \times 6, \mathrm{~A} \times 6, \mathrm{~B} \times 6$ \\
\hline B 12-1 & 4 & $\mathrm{~A} \times 12, \mathrm{~B} \times 12$ & $\mathrm{C} \times 12, \mathrm{D} \times 12$ & $\mathrm{~A} \times 12, \mathrm{~B} \times 12$ & $\mathrm{C} \times 12, \mathrm{D} \times 12$ \\
\hline-2 & 4 & $\mathrm{D} \times 12, \mathrm{C} \times 12$ & $\mathrm{~B} \times 12, \mathrm{~A} \times 12$ & $\mathrm{D} \times 12, \mathrm{C} \times 12$ & $\mathrm{~B} \times 12, \mathrm{~A} \times 12$ \\
\hline-3 & 4 & $\mathrm{~B} \times 12, \mathrm{~A} \times 12$ & $\mathrm{D} \times 12, \mathrm{C} \times 12$ & $\mathrm{~B} \times 12, \mathrm{~A} \times 12$ & $\mathrm{D} \times 12, \mathrm{C} \times 12$ \\
\hline-4 & 4 & $\mathrm{C} \times 12, \mathrm{D} \times 12$ & $\mathrm{~A} \times 12, \mathrm{~B} \times 12$ & $\mathrm{C} \times 12, \mathrm{D} \times 12$ & $\mathrm{~A} \times 12, \mathrm{~B} \times 12$ \\
\hline $\mathrm{R}$ & 16 & $(A \sim D) \times 24$ at random & $(A \sim D) \times 24$ at random & $(A \sim D) \times 24$ at random & $(A \sim D) \times 24$ at random \\
\hline
\end{tabular}

$\mathrm{A}$ からDは 4 種類のターゲットを表わす。数字は，それそれれのターダットの試行数を表わす。

$\mathrm{A} か ら \mathrm{D} の$ 位膡は次の通り。
A : $217.5^{\circ} \quad 160 \mathrm{~mm}$
B : $232.5^{\circ} \quad 80 \mathrm{~mm}$
角度は，右水平方向を0゚とした一般角で示してある。
C : $247.5^{\circ} \quad 120 \mathrm{~mm}$
距離はディスプレイ上の実測值で示してある。

\section{3. 手繶き}

練習セッションにおける 1 回の試行の手続き は次の通りである。被験者は，ブザーによる開 始の合図とともに，右手で保持したペンをボー ドのスタート位置の真上で構え， 3 秒後に提示 されるターゲット（表 1）を見てペンの移動方 向と速さを決定し，すぐにペンをスタート位置 につけ移動を開始した。なおぺンを動かす際， ベンが円坬の外に出るまで，途中で移動方向や 速度を変更しないよう，またもし変更が認めら れた場合には，データはキ+ンセルされるとい ら注意が与えられた。被検者は，ペン移動終了 直後にディスプレイに表示された追跡マークの 停止位粗 (KR) を確認し，すぐに左手でキーを 押すことが求められた。このキー反応は，次の 試行の開始の信号である。

練習セッションの効果を見るためのテスト セッションに拈いては，ペン移動終了直後の KR は与えられず，そのかわり左手に保持した マウスによって，追跡マークが停止したと思わ
れる地点を被験者自身に見積らせた。見積終了 後，すぐにディスプレイはクリフーされ，見積 に対する自信の程度の 5 段階評定尺度が表示さ れ，被験者はマウスによっていずれかを選択し た.

被験者に対するVTRによる課題の説明, ディスプレイ表示と反応計測，また以下の実験 スケジュールの制御等は，すべてコンピュータ とその周辺装置によって行なわれた。

\section{4. 荚殹㖕画}

被験者は，表 1 に示す 4 つの練習条件に割り 当てられそれぞれ 16 名よりなる 4 群が編成さ れた。コンスタント (C) 群は, 同一のターゲッ トだけを用いて練習を行った。ブロック 6(B 6) 群は，4種類のターゲットを用いて練習を行っ た。ただし，同一ターゲットに対して，連続 6 回練習した後，別のターゲットの練習に移行す るといらように，練習スケージュールに群化が 施された。ブロック 12 (B 12) 群は，12 回ずつ の群化とい5点を除き B 6 群と同じである。 
ンダム $(\mathrm{R})$ 群は，4 種類のターゲットを 6 回ず つ行らといら点はブロック群と同じであるが， ターゲットの提示順序は 1 回ごとにランダムに 変えられた。たたし，同一ターゲットが 2 度連 続しないように配虑された。なお、コンスタン 卜群，及びブロック群の被験者は，表 1 に示す ように 4 人ずつ 4 つのサブグループに分けられ た.

全ての被験者は, 24 試行を1セットとし，4 セット, 96 試行の練習を行った後, 練習とは異 なるターゲットで 12 試行のテストを 2 回受け た。このときのターダットは, 角度では $210^{\circ}$ か ら $270^{\circ}$, 距離では $35 \mathrm{~mm}$ から $165 \mathrm{~mm}$ の範囲 のそれぞれ異なる位膡に設定され，それらはラ ンダムな順序で提示された。練習セッション， テストセッションのいずれる, 試行間インター バルを 3 秒とし，七ット間インターバルを 1 分 とした。また 1 回目のテストは練習終了 1 分後 に行い(直後テスト)，2 回目は 1 週間後に行っ た（保持テスト）。

本実験で用いた測度は次の通りである，練習 セッションについては， 6 試行（1ブロック） ごとに角度と距離の絶対誤差 (AE) と変動誤差 （VE）を算出した。 また，予告音が鳴ってから 被験者がペンをボードにつけるまでおおび $\mathrm{KR}$ が提示されてから被験者が左手でキーを押 寸までの時間の 6 試行ごとの平均を，それぞれ プログラミング時間，KR 処理時間とした。

テストセッションについては, 12 試行の結果 より, 同様に $\mathrm{AE} と \mathrm{VE}$, 及びプログラミング時 間を算出した。なお角度に関しては，追跡マー クの停止角度からターダット角度を引いた 12 試行の平均（恒常誤差・CE）歹算出した，追跡 マークの移動する角度が, ボード上の動作方向 より左周りに 20 度ずれるようにしてあるので， 練習効果があがるはど，この測度のプラスの值 が小さくなることになる。

再認の測度としては，従来，実際の反応値と 見積られた値の差の絶対値の平均 (Benedetti and McCullagh', Henderson $^{10}$, Koch and Dorfman $^{11}$, 工藤 ${ }^{14)}$, Newell ${ }^{20)}$, Newell ${ }^{21}$,
Newell and $\mathrm{Chew}^{22)}$, Wallace, et $\mathrm{al}^{30)}$, Wallace

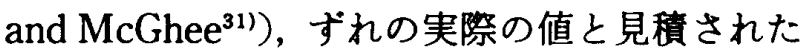
値との相関係数 (Benedetti and McCullagh'), Henderson $^{10)}$, Koch and Dorfman ${ }^{11)}$, Schmidt and White ${ }^{25)}$, Schmidt and Wrisberg $\left.{ }^{26)}\right)$ の 2 つの方法によって測られてきているが，ここで は，より多くの研究で採用されている前者の方 法を用いた(EAE)。また角度については，追跡 マークが停止した位置の角度から見積られた位 置の角度を引いた値の 12 試行の平均 (ECE) む 算出した. ECE はちょらど CEの逆の関係にな るので，練習効果があがるほどマイナスの值が 小さくなることになる。 また自己の見積に対す る自信の評定值の 12 試行の平均を求め, 自信得 点とした。

練習セッションの測度の分析に対しては，練 習要因 ( 4 群) $\times$ セット要因 ( 4 セット) メブロッ ク要因（4ブロック）の 3 要因分散分析 (repeated measures on the last two factors), テストセッションの測度の分析に対しては, 練 習要因 ( 4 群) ×保持要因 (直後テストと保持テ ス卜)の 2 要因分散分析 (repeated measures on the last factor）が適用された。

\section{III. 結果}

\section{1. 練翼セッションに成して}

表 2 は，練習セッションの各測度に対する分 散分析結果を示したものである。また図 2 と図 3 は，それぞれ角度の $\mathrm{AE}$ とブログラミング時 間の練習に伴う変化を示したものである，KR 処理時間を除く全てに共通して，3つの要因の 主効果及びセット要因とブロック要因の交互作 用が見られた。練習要因の主奻果について多重 比較を行ったところ，いずれの測度においても C 群が最もよく，B 6，B 12 群が中間に位圈し， $\mathrm{R}$ 群が最も悪いとい5結果であった。 B 6 群と B 12 群間に有意差は認められなかった。

全ての測度でセット要因とブロック要因の交 互作用がみられたので，それぞれ単純効果検定 を行ったところ，いずれも，第 1，第 2 セット でブロックの効果が有意であるのに対し，第 3 ， 
衣 2 、練習期の各測度に対する分散分析結果

\begin{tabular}{|c|c|c|c|c|c|c|c|c|c|c|c|c|c|c|c|c|c|c|c|c|}
\hline \multirow{3}{*}{ 変 } & \multirow{3}{*}{ 功 } & \multirow{3}{*}{ 因 } & \multicolumn{3}{|c|}{ 角 } & \multicolumn{3}{|c|}{ 度 } & \multicolumn{3}{|c|}{ 距 } & \multicolumn{3}{|l|}{ 峄 } & \multirow{2}{*}{\multicolumn{3}{|c|}{ プロクラミング時间 }} & \multirow{2}{*}{\multicolumn{3}{|c|}{ KR 処理時問 }} \\
\hline & & & \multicolumn{3}{|c|}{$\mathrm{AE}$} & \multicolumn{3}{|c|}{ VE } & \multicolumn{3}{|c|}{$\mathrm{AE}$} & \multicolumn{3}{|c|}{ VE } & & & & & & \\
\hline & & & $\mathbf{F}$ & df & $p$ & F & df & $\mathbf{p}$ & $\mathbf{F}$ & df & p & $\mathbf{F}$ & df & $\mathrm{p}$ & $\mathbf{F}$ & df & $\mathbf{p}$ & $\mathrm{F}$ & df & $\mathrm{p}$ \\
\hline 翼 & 要 & 因(A) & 32.64 & $3 / 60$ & $*$ & 74.44 & $3 / 60$ & ** & 30.89 & $3 / 60$ & ** & 44.02 & $3 / 60$ & ** & 11.32 & $3 / 60$ & ** & 0.64 & $3 / 60$ & \\
\hline$t y$ & 要 & 因(B) & 71.41 & $3 / 180$ & $\bullet$ & 33.67 & $3 / 180$ & •. & 49.72 & $3 / 180$ & ** & 39.16 & $3 / 180$ & .* & 21.67 & $3 / 180$ & ** & 196.73 & $3 / 180$ & *. \\
\hline プロッ & ク要 & 因(C) & 31.25 & $3 / 180$ & $\cdots$ & 31.62 & $3 / 180$ & •• & 32.70 & $3 / 180$ & $*$ & 27.53 & $3 / 180$ & ** & 47.12 & $3 / 180$ & $\cdots$ & 146.78 & $3 / 180$ & ** \\
\hline A & $x$ & B & 0.86 & $9 / 180$ & & 0.93 & $9 / 180$ & & 0.98 & $9 / 180$ & & 1.12 & $9 / 180$ & & 0.50 & $9 / 180$ & & 2.52 & $9 / 180$ & ** \\
\hline A & $x$ & $c$ & 1.13 & $9 / 180$ & & 2.65 & $9 / 180$ & •. & 0.97 & $9 / 180$ & & 0.78 & $9 / 180$ & & 3.25 & $9 / 180$ & *. & 1.23 & $9 / 180$ & \\
\hline B & $x$ & c & 13.15 & $9 / 540$ & *. & 9.08 & $9 / 540$ & *. & 14.97 & $9 / 540$ & .* & 18.00 & $9 / 540$ & $*$ & 12.00 & $9 / 540$ & $*$ & 83.78 & $9 / 540$ & ** \\
\hline A $>$ & B & & 1.28 & $27 / 540$ & & 1.29 & $27 / 540$ & & 0.59 & $27 / 540$ & & 0.91 & $27 / 540$ & & 1.67 & $27 / 540$ & • & 2.152 & $27 / 540$ & ** \\
\hline
\end{tabular}

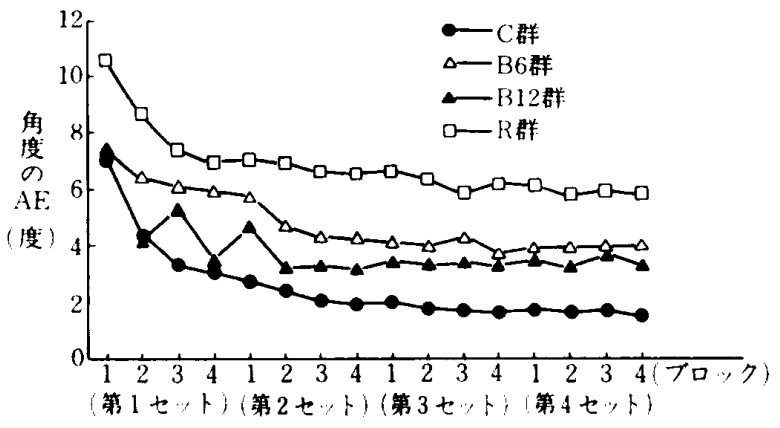

图2、角度の AEの練習曲線

第 4 セットで有意でなくなるとい5結果であっ たこれは，練習条件に関わらず，前半に練習 効果が急速に現れ，後半は定常状態になってい ることを意味している。

また, 角度の VE とプログラミング時間では， 練習要因とブロック要因との交互作用がみられ た。これは、 B 12 群の場合, 12 試行ずつの群化 を施したのに対し，B 6 群では 6 試行を 1 ブ ロックとして測度を算出したことにより，シク ザグのパターン（図 3）をとったことが影徆し たことによるすのであろう。

プログラミング時間と KR 処理時間では 2 次の交互作用が有意であったので，下位の検定 を行った結果，前者では練習要因とブロック要 因の交互作用 (B 12 群のシグザグのパターンに よる）が，第 4 セットではみられなくなるとい らことであり，後者ではランダム群のみ，第 1 セットの第 1 ブロックで有意に遅いということ であった。

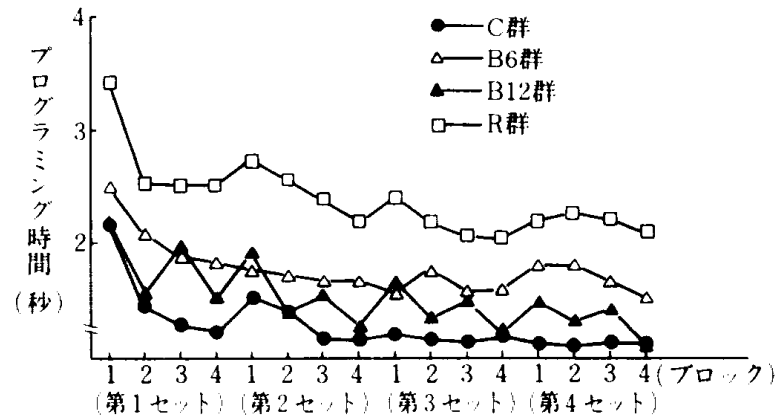

图 3.練習に伴 5プログラミング時間の変化

\section{2. テストセッションに閶して}

（1）再生機能，及びブログラミング時間 表 3 は，2 回のテストにおける再生パフォー マンス，及びプログラミング時間の平均と標準 偏差を示したあのであり，表 4 は，それらに対 する分散分析結果を示したものである。

角度の 3 つの測度に共通してみられるのは， 練習要因の主効果が有意であるという点であ る.それぞれ多重比較を行ったところ，AEでは C 群が最も悪く， B 6 群と R 群が最す優れてお ク，B 12 群がこの中間に位置するといらことで あった、B 6 群と R 群間に差はみられなかった。 また VEと CEでは，C群のみが他の 3 群より

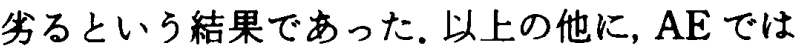
保持要因の主効果がみられ，全体として有意の 忘却が生じていることが明らかとなった。ただ し，練習要因との交互作用に有意の㑯向がみら れた。これは図 4 にみられるように，B 12 群が 特に大きな忘却を示す傾向にあるといらことで 
表3.2 回のテストにおける各群の再生バフーマンス,及びプログラミンク時間

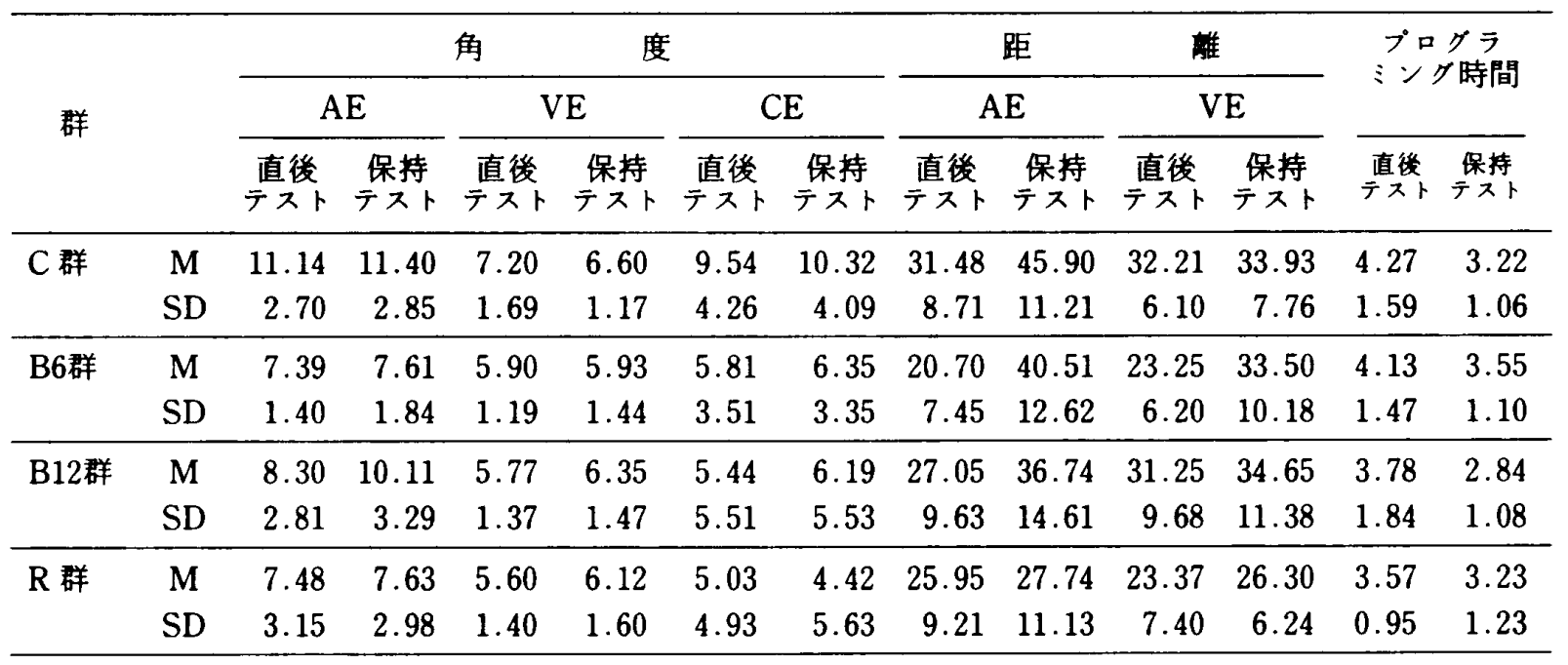

衰 4.2 回のテストにおける再生バフォーンス,及びブログラミンク時間に対する分散分析結果

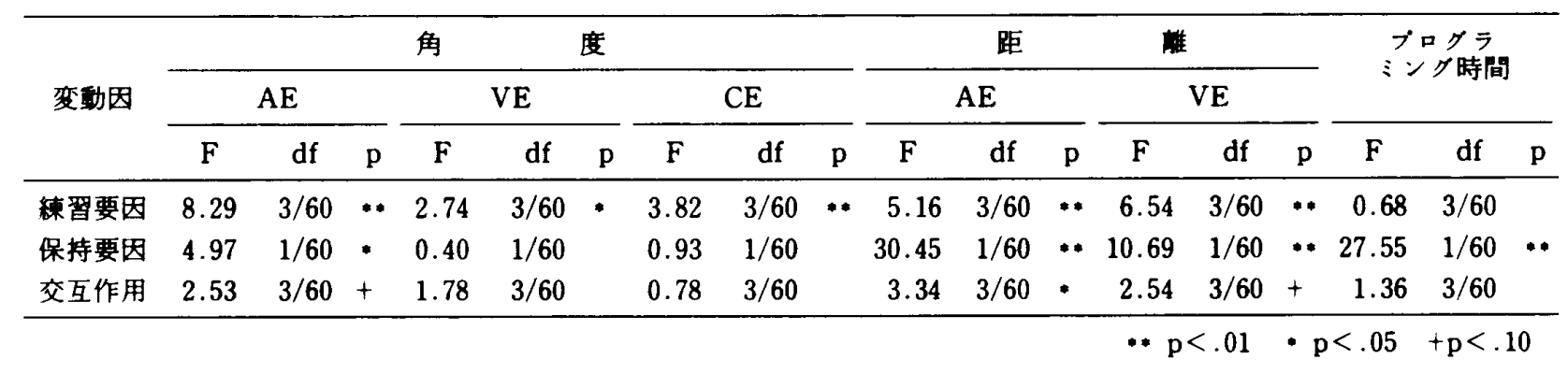

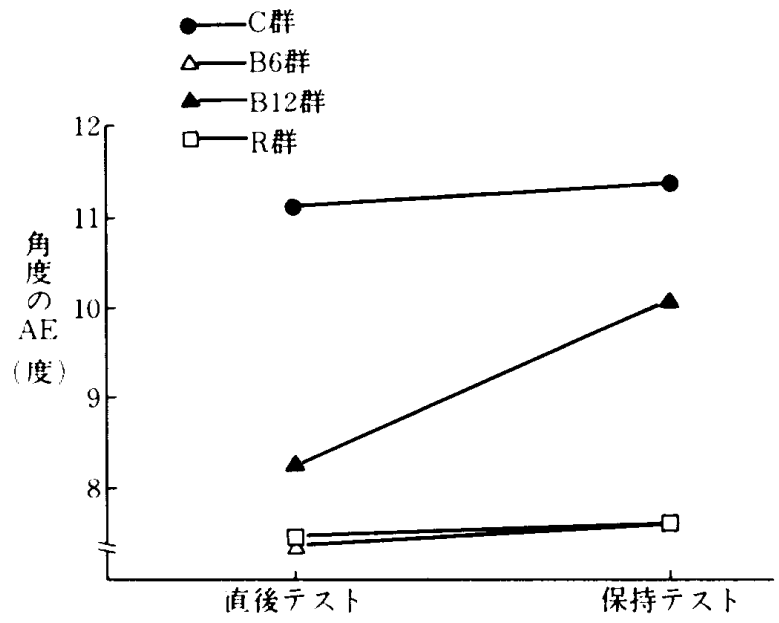

図4.直後テストと保持テストにおける角度の $\mathrm{AE}$

ある。

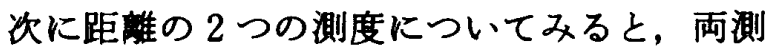
度とも練習要因と保持要因の主効果が有意で あった. AEで交互作用が有意であったので，単

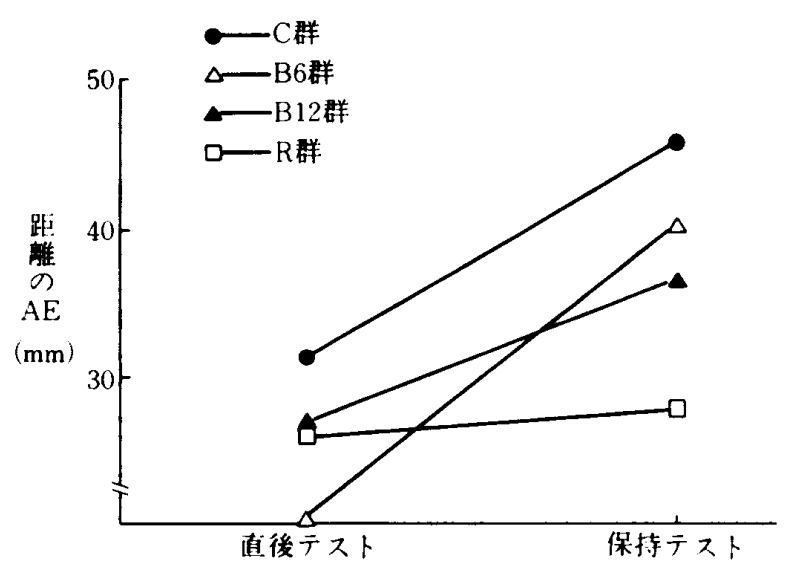

图 5.直後テストと保持テストにおける距崔の $\mathrm{AE}$

純効果検定と多重比較を行ったところ， R 群に おいては忘却がみられず，他の 3 群では有意の 忘却がみられるという結果であった。 また，図 5 に示すように，直後テストでは群間差は見ら れず，保持テストでは R 群のみが他の 3 群より 
衰 5.2 回のテストにおける各群の再認ハフォーマンス

\begin{tabular}{|c|c|c|c|c|c|c|c|c|c|}
\hline \multirow{3}{*}{ 群 } & & \multirow{2}{*}{\multicolumn{2}{|c|}{$\mathrm{EAE}$}} & \multicolumn{2}{|l|}{ 度 } & 距 & 離 & \multirow{2}{*}{\multicolumn{2}{|c|}{ 自信得点 }} \\
\hline & & & & \multicolumn{2}{|c|}{ ECE } & \multicolumn{2}{|c|}{ EAE } & & \\
\hline & & 直後テスト & 保持テスト & 值後テスト & 保持テスト & 直後テスト & 保持テスト & 直後テスト & 保持テスト \\
\hline \multirow[t]{2}{*}{ C 群 } & $\mathbf{M}$ & 11.06 & 12.41 & -9.69 & -11.34 & 26.16 & 40.00 & 3.09 & 2.90 \\
\hline & $\mathrm{SD}$ & 2.34 & 2.49 & 3.34 & 3.30 & 12.60 & 17.29 & 0.46 & 0.72 \\
\hline \multirow[t]{2}{*}{ B6群 } & $\mathrm{M}$ & 7.28 & 7.71 & -4.53 & -6.21 & 26.81 & 41.52 & 3.16 & 2.77 \\
\hline & $\mathrm{SD}$ & 2.17 & 2.25 & 3.06 & 3.02 & 8.04 & 17.81 & 0.67 & 0.51 \\
\hline \multirow[t]{2}{*}{ B12群 } & $\mathbf{M}$ & 7.93 & 10.21 & -4.13 & -7.29 & 24.84 & 39.24 & 3.09 & 2.65 \\
\hline & $\mathrm{SD}$ & 2.84 & 3.23 & 4.71 & 5.17 & 11.37 & 16.97 & 0.73 & 0.65 \\
\hline \multirow[t]{2}{*}{$\mathrm{R}$ 群 } & $\mathbf{M}$ & 6.98 & 8.41 & -4.78 & -4.43 & 21.92 & 27.75 & 3.07 & 2.76 \\
\hline & $\mathrm{SD}$ & 1.36 & 2.68 & 2.22 & 3.66 & 12.44 & 12.38 & 0.39 & 0.70 \\
\hline
\end{tabular}

衰 6.2 回のテストにおける再認ハフォーマンスに対する分散分析結果

\begin{tabular}{|c|c|c|c|c|c|c|c|c|c|c|c|c|}
\hline \multirow{3}{*}{ 变動因 } & \multicolumn{3}{|c|}{ 角 } & \multicolumn{2}{|l|}{ 度 } & & 距 & 離 & & \multirow{2}{*}{\multicolumn{3}{|c|}{ 自信得点 }} \\
\hline & \multicolumn{3}{|c|}{$\mathrm{EAE}$} & \multicolumn{3}{|c|}{$\mathrm{ECE}$} & \multicolumn{3}{|c|}{ EAE } & & & \\
\hline & $F$ & df & $\mathrm{p}$ & $\mathrm{F}$ & df & $p$ & $F$ & $\mathrm{df}$ & $\mathrm{p}$ & $\mathrm{F}$ & $\mathrm{df}$ & $\mathrm{p}$ \\
\hline 緗習要因 & 13.65 & $3 / 60$ & $* *$ & 10.36 & $3 / 60$ & $* *$ & 2.78 & $3 / 60$ & . & 0.18 & $3 / 60$ & \\
\hline 保持要因 & 16.60 & $1 / 60$ & ** & 13.61 & $1 / 60$ & ** & 31.78 & $1 / 60$ & ** & 15.29 & $1 / 60$ & ** \\
\hline 交互作用 & 1.27 & $3 / 60$ & & 3.02 & $3 / 60$ & * & 1.01 & $3 / 60$ & & 0.42 & $3 / 60$ & \\
\hline
\end{tabular}

優れているといら結果であったまたVEの綀 習要因の主効果に対して多重比較を行ったとこ ろ, C 群と B 12 群が最も坌り, B 6 群がこれに 続き， $\mathrm{R}$ 群が最も優れているといら結果であっ た。 また保持要因の主効果が有意であったとい らことは，全体として有意の忘却がみられたと いうことである。ただ，ここです交互作用に 有意の傾向がみられた。それは，B 6 群において 特に䫓著な忘却がみられるといらことである。

プログラミング時間では, 保持要因のみが有 意であり，保持テストの方が時間が短いという 結果であった。

\section{(2) 再認機能}

表 5 は, 2 回のテストにおける再認パフォー マンスの平均と標準偏差を示したものであり， 表 6 はそれらに対する分散分析結果をまとめた あのである。

自信得点を除き, 他の 3 つの再認機能に関わ

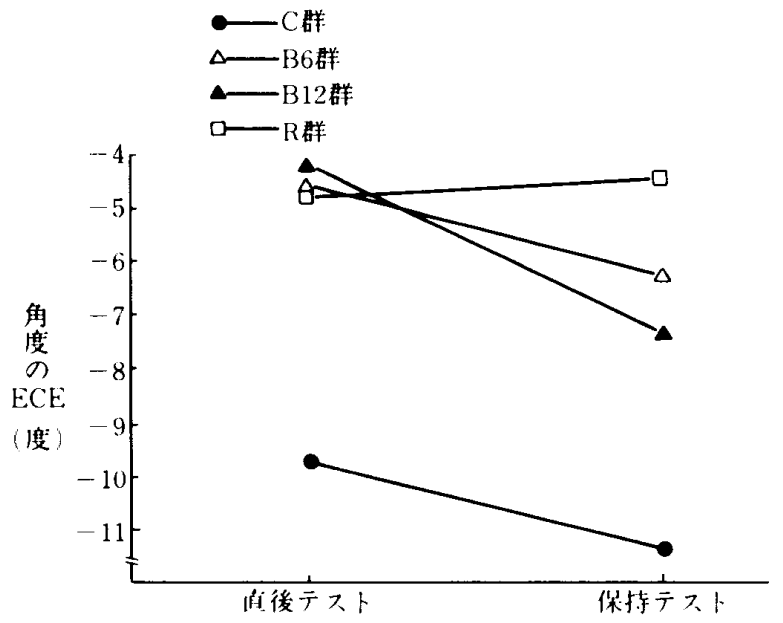

图6.直後テストと保持テストにおける角度の ECE

る測定では, 練習要因と保持要因の主効果が有 意であった，多重比較の結果，角度の $\mathrm{EAE}$ と ECE (図 6) では，C群のみが他の 3 群より有 意に贫るという結果であり, 距離の EAE（図 7) 


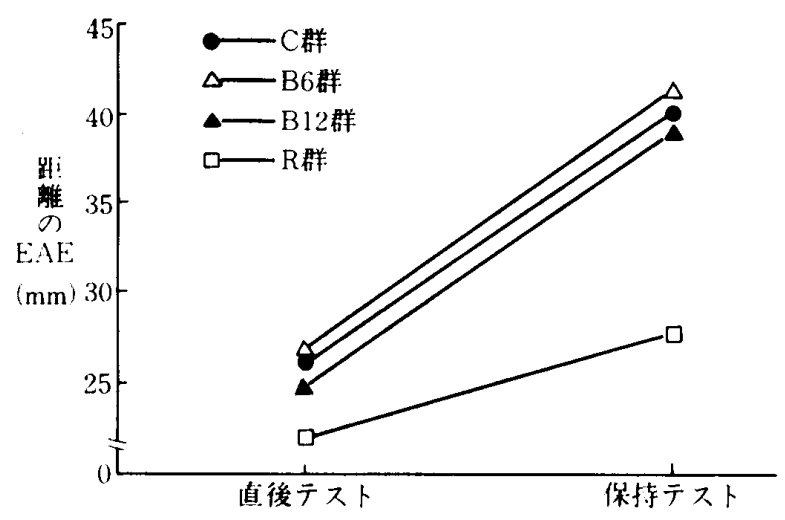

图7.直後テストと保持テストにおける距離の EAE

では $\mathrm{R}$ 群のみが優れているという結果であっ た。 また，保持要因の主効果の意味は，全体と して有意の忘却がみられるということである。 ただし，角度のECEにおいて交互作用が有意 であったので，単純効果検定を行ったところ， $\mathrm{R}$ 群だけは忘却がみられず，他の 3 群では有意 の忘却がみられるといら結果であった（図6）。 自信得点に拈いては，保持要因のみが有意であ りこれは再テストまでの間に再認に対する確 信度が低下することを示するのである。

\section{IV. 考察}

練習セッションでは，C群のパフォーマンス が最も優れ， $\mathrm{R}$ 群が最も悪く，2つのブロック 群が中間に位置するといら結果であり，ブログ ラミング時間では, $\mathrm{C}$ 群が最も短く, $\mathrm{R}$ 群が最も 長く, 2 つのブロック群がこれらの中間に位置 寸るという結果であった，分脈干涉の程度の違 ら2つのブロック群間に，パフォーマンスの明 確な差はみられなかったが，プログラミンク時 間においては，第 4 セットを除くすべてのセッ トで，B 6 群に比べ B 12 群は第 2 , 第 4 ブロッ クにおけるプログラミング時間の短縮がみられ た。練習セッションにおけるこれらの結果は, 多様性練習仮説あるいは分脈干涉効果を調へる ための前提条件がほぼ満たされたことを意味し ている. KR 処理時間では, 第 1 セットの第 1 フ ロックで $\mathrm{R}$ 群のみが遅いといらこと以外, 練習 条件による相違はみられなかった。練習セッ
ションにおける以上のような群間差を前提にし て，以下にテスト時のパフォーマンスの結果に ついて考察する。

まず,単に練習に多様性をるたせるだけでも， 転移と保持に対して促進効果がみられるかを調 べるために，分脈干渉という点では大きな差は なく、多様性という点において異なる B 12 群と $\mathrm{C}$ 群の結果を比較してみる。角度に関しては, 再 認，再生ともに，いずれのテストにおいても B 12 群の方がC 群より優れているという結果 が得られた。これに対しし，B 12 群の方が保持 に怙いて，C群より優れていることを示寸結果 は得られなかった。このことは, 再生と再認と もに，角度の側面では多様性練習による転移に 対する促進効果を確認することはできたが，保 持に対する促進効果の方は確認できなかったこ とを意味している。一方，距離に関しては，再 生と再認ともに，テスト時期に関わらずいずれ においてもB 12 群とC 群間に差はみられな かった。このことは, 角度とは異なり, 距離に おいては多様性練習仮説における転移と保持の 促進効果のいずれもが支持されなかったことを 意味する。

角度と距離で，このような結果の相違が見ら れたことに対しては，次のよらに解釈すること ができる．今回の動作課題では，動かした方向 に対して結果が常に 20 度同一方向にずれると いうものであった。これは，一旦ずれの程度が わかれば，あとはどの方向のターゲットに対し ても，被験者は容易に対応できたと考えること ができる、このように，動作と動作結果との間 に、既にしっかりとした対応関係ができており， その関係の企法則を見つけることが主な学習 内容となっている場合にのみ，多様性練習仮説 が支持されるのではないかと考えられる。

つぎに，分脈干渉の影警を調べるために，多 様性において等しく，分脈干涉の程度において 異なる R 群, B 6 群, 及び B 12 群の結果を比較 すると，角度と距離とに関わらず，再生と再認 のいずれにおいても比較的一貫した結果が得ら れた。すなわち， R 群だけはほとんどの測度に 
おいて忘却が生じなかったのに対し，B 12 群と B 6 群では有意の忘却が生じたのである。距離 の VEでは, C 群と B 12 群に忘却は生じていな いが，それは，この測度では練習による向上が， これらの 2 群であまり見られなかったためと考 えられる。また，2つのブロック練習群の保持 に関する結果をみると，大きな差はみられない が, 角度の AEでは, B 6 群は B 12 群より優れ, $\mathrm{R}$ 群に匹敵する成䋡を示している，以上の結果 は，分脈干涉が強いはと，保持に対する促進効 果があることを示しているものと考えられる。

また，分脈干渉による転移に対する促進効果 を調へるために，直後テストにおける R 群と 2 つのブロック群の成筫を比較してみると， $\mathrm{R}$ 群

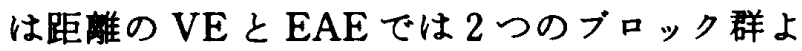
り優れており，角度の AEではB 12 群より優れ

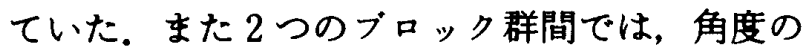
$\mathrm{AE}$ と距離の VEでB 6 群の方が B 12 群より 传れていた。これらは，保持に対する促進奻果 ほど明確ではないが，分脈干涉は転移に対して す促進的に作用することを示している.

最後に，2 回のテストにおけるプログラミン 時間について考察する，直後，保持いずれのテ ストセッションにおいても，プログラミング時 間の群間差はみられなかった。このことは少な くとも，練習条件の相違が転移課題遂行のため のプログラミング時間には影荇しないこと，ま たプログラミングの時間の長さそのものは, 動 作の正確性には影慗しないことを示するのであ る. Lee, et al. ${ }^{18)}$ は, 練習セッション, テストセッ ションともに潐備時間（今回のプログラミング 時間に相当）に条件差がみられたと報告してい るが，以上の結果は，テストセッションに関し ては明らかに異なっている。一方工藤 は12),13),15)，一定の経験を積んた動作において は,プログラミングの時間的な長さは動作の正 確性に影需しないことを示しているが，今回の 結果はこれらと共通している，ところで，Lee， et al.の研究では準備時間が計測されることは 被検者にいっさい知られていないのに対し，本 研究では実験装置の配置の関係上, ターゲット
提示から反応開始までの時間が計測されている ことが，被験者にはわかるよらになっている。 このような違いが，テストセッションにおける 結果の相違の原因になっているのではないかと 考えられる。

プログラミング時間に関しては更に，保持イ ンターバルによって短縮するといら結果が得ら れた。これとテスト時のパフォーマンスの結果 とを対応させると,動作の忘却が生じることと， プログラミング時間が短縮することの間になん らかの関係があることが想像される、すなわち, 入念なプログラミングは，プログラミングすべ きものがある程度はっきりしていてこそ意味が あるのであって，プログラミングの材料が㖟昧 になれば，いくら時間をかけても無䭾な努力と なる、被験者のこのような認識が，保持テスト の動作開始時間に影響したものと思われる。

\section{V. と め}

全体的に見ると，再生と再認においてきわめ て類似した結果が得られた。したがって，その 原因は別としても，練習に多様性をもたせるこ と，あるいはスシュールを変えることは，再生 と再認それぞれにほぼ同様の効果をもたらすと いってょいだろう。

さて，今回の結果から，多様性練習仮説を明 確に支持する結果を得ることはできなかった。 唯一，転移の促進効果に夙しては，角度に関す る測度において検証されたに過ぎない。

これに対して，分脈干渉による影㱖について は，ある程度明確な結果が得られた。練習の多 様性に打いて等しく，分脈干涉の程度の異なる 3 群の比較を要約すれば， $\mathrm{R}$ 群が直後，保持テ ストいずれにおいても2つのブロック練習群よ り優れており，しかもはとんどの測度において 忘却がみられなかったのに対し，2つのブロッ ク練習群ではコンスタント条件之同様の忘却が みられたということである。また分脈干渉の程 度の異なる 2 つのブロック練習群間にも，明確 ではないが，予想されるよらな方向での差がみ られた。本研究で得られた以上の結果は，多様 
性練習による転移と保持に対する促進効果は， 主として練習スケージュールによる分脈干渉に よって生じたものであることを強く示唆してい る.

さて, 今回はプログラミング時間, KR 処理時 間の両方を測定したが，前者に関しては，綀習 セッションにおける時間が長いほど，保持にお いて優れているといら結果であった。このこと は，分脈干渉による動作遂行前の試行ごとのプ ログラミングが，動作の保持と転移を促進する といら Lee, et al. ${ }^{18)}$ の考光かたを支持してい る.これに対し, KR 処理時間については明確な 結果は得られなかった。

ところで，今回の実呀す含め，これまでの実 験では，分脈干啮による事前の情報処理の仕方 は, 練習スケジュールの違いによって間接的に 操作しているに過ぎない，今回のよ5に反応時 間をとることは，これらの実験操作の客観化の $1 つ の$ 方法ではあるが，明確な結論を得るため には，より直接的な実験操作を工夫する必要が あるだろう。また, KR 処理時間については明確 な結果は得られなかったが，練習のごく初期で はあるが， $\mathrm{R}$ 群のみが他の 3 群よりも $\mathrm{KR}$ 処理 時間が長いという結果が得られている。また最 近, 動作終了後の情報処理活動之保持との関係 についても積極的に分析されるようになってき ていることなどから (Swinnen) ${ }^{28)}$, KR 処理を も含めたこれらの情報処理活動が動作の習得に 与える影敕について，今後更に検討する必要が あると思われる。

\section{引用・参考文献}

1) Battig, W.F., "The flexibility of human memory," in Cermak, L.S. and Craik, F.I.M. (Eds.), Levels of processing and human memory, N.J. Hillsdale, Erlbaum : 1979. pp. 23-44.

2) Benedetti, C. and McCullagh, P., "Postknowledge of results delay : Effects of interpolated activity on learning and performance," Research Quarterly for Exercise and Sport, 58 : 375-81, 1987.

3) Del Rey, P., "Effects of contextual interference on the memory of older females differing in levels of physical activity," Perceptual and Motor Skills, 55 : 171-80, 1982.

4) Del Rey, P., Whitehurst, M. and Wood, J.M., "Effects of experience and contextural interference on learning and transfer by boys and girls," Perceptural and Motor Skills, 56 : 581-82, 1983.

5) Del Rey, P., Wughalter, E., Du Bois, D. and Carnes, M.M., "Effects of contextual interference and retention intervals on transfer," Perceptural and Motor Skills, $54: 467-76,1982$.

6) Del Rey, P., Wughalter, E.H. and Whitehurst, M., "The effects of contextual interference on females with varied experience in open sport skills," Research Quartery for Exercise and Sport, 53 : 105-15, 1982.

7) Gabriele, T.E., Hall, C.R. and Buckolz, E.E., "Practice schedule effects on the acquisition and retention of a motor skill," Human Movement Science, $6: 1-16,1987$.

8) Gabriele, T.E., Hall, C.R. and Lee, T.D., "Cognition in motor learning : Imagery effects on contextual interference," Human Movement Science, $8: 227-45,1989$.

9) Goode, S. and Magill, R.A., "Contextual interference effects in learning three badminton serves," Research Quanterly for Exercise and Sport, 57 : 308-14, 1986.

10) Henderson, S.E., "Predicting the accuracy of a throw without visual feedback," Journal of Human Movement Studies, 1:183-89, 1975.

11) Koch, C.G. and Dorfman, P.W., "Recall and recognition processes in motor memory : Effects of feedback and knowledge of results delay," Journal of Motor Behavior, 11:23-34, 1979.

12）工藤孝機「動作の困難性と反応の遅れ」福島大学教 育学部論集, $37: 43-52,1985$.

13）工藤孝機「パリスティック動作におけるプロクラミ ンク時間と反応の正確性との関俰」福島大学教育学 部論集, $40: 25-32,1986$.

14）工藤孝幾「動作プロクラムの調整ミス：篹囲奻果の 検討」体育の科学, $37: 129-33,1987$.

15）工藤孝幾「運動反応スキーマの形成を調べるための 新たな動作課題の開発」福島大学教育学部論集, 46 : $1-16,1989$.

16) Lee, T.D. and Magill, R.A., "The locus of contextual interference in motor skill aquisition," Journal of Experimental Psychology: Learning, Memory, and Cognition, $9: 730-46,1983$.

17) Lee, T.D. and Magill, R.A., "Can foregetting facilitate skill acquisition?" in Goodman, D., Wilberg, R.B. and Frnks, I. (Eds.), "Differing 
perspectives in motor learning, memory, and control," North-Holland : Amsterdam, 1985. pp. $13-22$.

18) Lee, T.D., Magill, R.A. and Weeks, D.J., "Influence of practice schedule on testing schema theory predictions in adults," Journal of Motor Behavior, $17: 283-99,1985$.

19) Moxley, S.E., "Schema : The variability of practice hypothesis," Journal of Motor Behavior, 11 : 65-70, 1979 .

20) Newell, K.M., "Knowledge of results and motor learning," Journal of Motor Behavior, 6: 235 $-44,1974$

21) Newell, K.M., "Visual flight feedback as a determiner of motor response recognition," Research Quartery for Exercise and Sport, 46: 235-42, 1975.

22) Newell, K.M. and Chew, R.A., "Recall and recognition in motor learning," Journal of Motor Behavior, 6 : 245-53, 1974.

23) Pigott, R.E. and Shapiro, D.C., "Motor schema : The structure of the variability session," Research Quartery for Exercise and Sport, $55: 41$ $-45,1984$.

24) Schmidt, R.A., "A schema theory of discrete motor skill learning," Psychological Review, 82 : 225-60, 1975.

25) Schmidt, R.A. and White, J.L., "Evidence for an error detection mechanism in motor skills: A test of Adams' closed-loop theory," Journal of Motor Behavior, 4 : 143-53, 1972.

26) Schmidt, R.A. and Wrisberg, C.A., "Futher tests of Adams' closed-loop theory: responseproduced feedback and the error detection mech anism," Journal of Motor Behavior, $5: 155-64$, 1973.

27) Shea, J.B. and Morgan, R.L., "Contextual interference effects on the acquisition, retention, and transfer of a motor skill," Journal of Experimental Psychology : Human Learning and Memory, 5: 179-87, 1979.

28) Swinnen, S., "Post-performance activities and skill learning," in Meijer, OL.G. and Roth, K. (Eds.), "Complex movement behavior: 'The' motor-action controversy," North-Holland : Amsterdam, 315-38, 1988.

29) Turnbull, S.D. and Dickinson, J., "Maximizing variability of practice: A test of schema theory and contextual interference theory," Journal of Human Movement Studies, 12 : 201-13, 1986.

30) Wallace, S.A., DeOreo, K.L. and Roberts, G.C., "Memory and perceptual trace development in ballistic timing," Journal of Motor Behavior, 8 : 133-37, 1976.

31) Wallace, S.A. and McGhee, R.C., "The independence of recall and recognition in motor learning," Journal of Motor Behavior, 11: 141-51, 1979.

32) Whitehurst, M. and Del Rey, P., "Effects of contextual interference, task difficulty, and levels of processing on pursuit tracking," Perceptual and Motor Skills, 57 : 619-28, 1983.

33) Wrisberg, C.A. and Mead, B.J., "Developing coincident timing skill in children : A comparison of training methods," Research Quartery for Exercise and Sport, $54: 67-74,1983$.

(平成 2 年 9 月 19 日受付) 